\title{
UJIAN PRAKTIKUM HISTOLOGI DENGAN TAYANGAN FOTO MENGHASILKAN SKOR YANG LEBIH TINGGI
}

\author{
Rina Susilowati, Jajah Fachiroh, Yustina Andwi Ari Sumiwi \\ Departemen Histologi dan Biologi Sel, Fakultas Kedokteran Universitas Gadjah Mada
}

\begin{abstract}
Background: Since 2003, Histology practical session in Faculty of Medicine Universitas Gadjah Mada as well as its assessment had been subjected into several changes, i.e. methods of practical asessment and the usage of practical session score as block score components. Score of practical session assessments has been used as marker of student's achievement in mastering the learning objectives. This study compared practical session score of Histology practical assessment between student from batch 2003-2006, 2007-2010 and 2011-2012, in order to determine which method give highest student achievement.

Method: Score of histology practical assessment from 3 groups of medical students were obtained from the archive. The data was reported as mean $\pm S D$ and number distribution of the students with score $\geq 60$. The difference between groups was analyzed using t-test and chi-square.

Results: There were 2213 students included in this study, i.e. 735 of year 2003-2006 (microscope-based test, score used as component of block score), 920 of year 2007-2010 (microscope-based test, score not used as component of block score), and 558 of year 2011-2012 (micrograph-based test, score was used as component

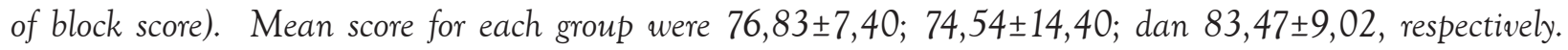
Percentage of students with score $\geq 60$ were $83,59 \%, 73 \%$, dan 97,49\%. There were significant difference between groups $(P<0.0001)$.

Conclusion: Score of histology practical assessment was higher in students tested with micrographs visualized by projector. The percentage of students with score $\geq 60$ was higher when the score was used as component of block score.
\end{abstract}

Keywords: histology, practical session, assessment, micrograph

\section{ABSTRAK}

Latar belakang: Sejak tahun 2003 metode penyelenggaraan praktikum dan ujian praktikum Histologi di Fakultas Kedokteran Universitas Gadjah Mada (UGM) mengalami beberapa perubahan seperti metode ujian dengan menggunakan tayangan foto dan penggunaan skor praktikum dalam penghitungan skor akhir blok. Skor ujian praktikum digunakan sebagai penanda pemahaman mahasiswa terhadap materi yang dipelajari. Laporan ini membandingkan skor ujian praktikum antar program 2003-2006; 2007-2010, dan 2011-2012, untuk melihat metode mana yang menghasilkan skor ujian praktikum yang paling baik.

Metode: Skor ujian praktikum tiga kelompok yaitu mahasiswa S1 pendidikan dokter Fakultas Kedokteran UGM reguler angkatan 2003-2006, 2007-2010 dan 2011-2012 didapatkan dari arsip. Skor dikelompokkan menjadi kelompok $<60$ dan $\geq 60$. Rerata skor dan distribusi frekuensi skor $<60$ dan $\geq 60$ per kelompok dilaporkan dan dianalisis secara statistik menggunakan uji t dan chi-square. Hasil: Skor praktikum dari 2213 mahasiswa, terdiri dari 735 orang angkatan 2003-2006 (ujian dengan mikroskop, skor menjadi komponen skor blok), 920 orang angkatan 2007-2010 (ujian dengan mikroskop, skor tidak menjadi komponen skor blok), dan 558 orang angkatan 2011-2012

korespondensi: rina_susilowati@ugm.ac.id 
(ujian dengan tayangan foto, skor menjadi komponen skor blok) berhasil dianalisis. Rerata skor setiap kelompok berturut-turut adalah 76,83 $\pm 7,40 ; 74,54 \pm 14,40$; dan $83,47 \pm 9,02$. Persentase jumlah mahasiswa dengan skor ujian praktikum $\geq 60$ adalah 96,73\%; 83,59\%, dan 97,49\%. Perbedaan antara ketiga kelompok tersebut bermakna secara statistik $(\mathrm{P}<0.0001)$.

Kesimpulan: Rerata skor ujian praktikum Histologi lebih tinggi pada mahasiswa yang diuji dengan tayangan foto. Penggunaan skor praktikum sebagai komponen skor akhir blok menghasilkan jumlah mahasiswa dengan skor praktikum Histologi $\geq 60$ yang lebih banyak.

Kata kunci: histologi, praktikum, ujian, tayangan foto

\section{PENDAHULUAN}

Histologi adalah ilmu yang mempelajari struktur mikroskopis sel dan jaringan tubuh yang normal. Ilmu ini merupakan dasar pemahaman patologi penyakit, diagnosis dan praktik medis serta penelitian di bidang kedokteran dan kesehatan. Mahasiswa pendidikan dokter perlu mempelajari histologi untuk memahami kaitan antara struktur mikroskopik dan fungsi sel serta jaringan. Untuk mempelajari Histologi diperlukan kemampuan mengamati gambaran dua dimensi dari jaringan dan organ yang merupakan struktur tiga dimensi.

Praktikum Histologi merupakan salah satu praktikum dasar pada program studi pendidikan Dokter. Praktikum ini secara tradisional dilakukan dengan cara memberi tugas pada mahasiswa untuk mengamati sediaan awetan pada gelas obyek menggunakan mikroskop cahaya. Tradisi menggambar sediaan yang diamati juga merupakan suatu metode pembelajaran yang lazim dilakukan di banyak tempat ketika atlas dan foto preparat masih belum banyak didapatkan. Gambar yang dibuat oleh mahasiswa dapat digunakan sebagai catatan dan dapat menggambarkan pemahaman mahasiswa pada struktur yang diamati. Namun demikian untuk dapat menghasilkan gambar yang baik diperlukan waktu yang cukup lama sementara pada kurikulum baru terdapat kecenderungan pengurangan alokasi waktu untuk praktikum. Di sisi lain, teknologi digital amat berkembang sehingga mahasiswa dapat dengan mudah membuat foto sediaan dengan kamera pada telepon genggamnya. Kebutuhan akan atlas juga semakin mudah dipenuhi dengan adanya foto sediaan histologi yang tersedia di jaringan internet. Karena itu, menggambar bukan lagi menjadi metode yang menarik bagi mahasiswa dan bahkan dapat memberi beban yang tidak perlu mengingat alokasi waktu praktikum yang sempit.

Sejak tahun 2003 hingga tahun 2012, mahasiswa Program Studi Pendidikan Dokter Fakultas Kedokteran Universitas Gadjah Mada (UGM) mengikuti perubahan kurikulum yang juga berdampak pada pengurangan jumlah sesi dan alokasi waktu praktikum. Pada kurun waktu tersebut, terjadi juga perubahan distribusi praktikum histologi pada berbagai blok. Pada awalnya, metode tradisional menggambar preparat diwajibkan pada semua mahasiswa. Gambar tersebut diserahkan di akhir praktikum kemudian diberi skor dan catatan perbaikan oleh instruktur. Karena adanya pengurangan waktu praktikum dari 3 jam menjadi 2 jam setiap sesinya, waktu yang ada tidak cukup lagi untuk menghasilkan gambar yang baik. Mahasiswa cenderung untuk menyelesaikan gambar tanpa sempat melakukan pengamatan sediaan dengan sungguh-sungguh. Karena itu metode mendapatkan skor praktikum diganti dengan kuis akhir praktikum yang dilakukan 20 menit sebelum waktu praktikum berakhir. Kuis ini dilakukan dengan memperlihatkan hasil cetak foto preparat pada mahasiswa dan menunjuk salah satu struktur yang ada sebagai bagian dari soal. Namun demikian mahasiswa masih diwajibkan mencari dan mengamati struktur yang dipelajari dengan mikroskop.

Sejak tahun 2003, ujian praktikum histologi dijadwalkan pada setiap akhir blok. Ujian praktikum histologi yang dilakukan di awal perubahan kurikulum tersebut juga menggunakan peragaan sediaan di bawah mikroskop dengan jarum penunjuk yang menjadi penanda struktur yang ditanyakan. 
Mahasiswa mengamati setiap sediaan dan menjawab soal yang diberikan, seperti ban berjalan berputar mengamati sekitar 30 mikroskop yang disiapkan penguji. Bila jumlah mahasiswa banyak dan mikroskop yang tersedia sedikit, maka mahasiswa harus menunggu giliran cukup lama untuk dapat mengikuti ujian. Di masa sekarang, teknologi foto digital memungkinkan pengamatan sediaan pada layar monitor komputer. Beberapa fakultas kedokteran juga melaporkan bahwa penggunaan mikroskop virtual pada program pembelajaran histologi juga meningkatkan pemahaman mahasiswa. ${ }^{1}$ Ujian menggunakan tayangan foto di layar komputer juga dilaporkan meningkatkan skor ujian praktikum. ${ }^{2}$

Metode ujian praktikum yang dikembangkan di Fakultas Kedokteran UGM kemudian adalah dengan menayangkan foto preparat di kelas sebagai soal ujian. Gambar panah, bintang dan lingkaran digunakan sebagai penunjuk struktur yang dimaksud pada soal. Dengan asumsi bahwa skor ujian praktikum menggambarkan pemahaman mahasiswa pada struktur dan fungsi sel, jaringan dan organ yang dipelajari saat praktikum, penelitian ini bertujuan membandingkan skor ujian praktikum antar program angkatan 2003-2006; 2007-2010, dan 2011-2012 untuk melihat metode praktikum mana yang menghasilkan skor ujian praktikum yang paling baik.

\section{METODE}

Data diambil dari arsip petunjuk praktikum dan arsip skor ujian praktikum pada kurun waktu sepuluh tahun, 2003 hingga 2012. Perubahan sistem praktikum dan ujian terjadi pada angkatan 20032006, 2007-2010 dan 2011-2012 sehingga mahasiswa dikelompokkan dalam periode tersebut. Sebaran praktikum Histologi, jumlah sesi praktikum, jumlah preparat yang diamati, sumber skor praktikum (dari penilaian gambar mahasiswa atau dari kuis akhir praktikum) dan metode ujian pada masing-masing periode tersebut dicatat.
Skor praktikum mahasiswa didapat dari penjumlahan jawaban yang benar dari seluruh ujian praktikum histologi yang diikuti oleh mahasiswa tersebut dibagi dengan jumlah soal yang diujikan pada seluruh ujian praktikum yang diikuti oleh mahasiswa dikalikan 100. Hanya ujian praktikum pertama saja yang diambil datanya sedangkan skor ujian praktikum ulangan tidak diikutsertakan pada analisis data. Skor pada tiap kelompok mahasiswa dengan kelompok program praktikum yang berbeda dilaporkan sebagai rerata \pm simpang baku. Perbedaan rerata antar kelompok dibandingkan dengan uji $\mathrm{T}$. Distribusi frekuensi skor praktikum $<60$ dan $\geq 60$ dibandingkan antar kelompok. Skor 60 digunakan sebagai pembeda karena skor tersebut merupakan batas mahasiswa mendapatkan surat puas pada periode 2007-2010. Perbedaan antar kelompok diuji dengan chi-square.

\section{HASIL DAN PEMBAHASAN}

Perbedaan program praktikum dan ujian praktikum Histologi pada ketiga kelompok dapat dilihat pada tabel 1. Pada angkatan 2003-2006, program praktikum Histologi terbagi menjadi 8 blok, terdiri dari 19 sesi dan mengamati 65 preparat. Mahasiswa diwajibkan menggambar sediaan yang diamati dan gambar tersebut diberi skor oleh instruktur praktikum. Pada tahun 2007-2012, praktikum Histologi tersebar dalam 5 blok. Ada 17 sesi praktikum yang digunakan untuk mengamati 50 preparat. Mahasiswa tidak lagi diwajibkan menggambar, namun komponen skor praktikum diganti dengan kuis akhir praktikum. Pada angkatan 2007-2010, skor praktikum tidak digunakan sebagai komponen skor akhir blok namun skor praktikum minimal 60 digunakan sebagai dasar pemberian surat puas. Bila surat puas tidak didapatkan, nilai blok tidak akan dikeluarkan. Untuk mendapatkan surat puas, mahasiswa diberi kesempatan mengulang ujian praktikum. 
Tabel 1. Gambaran kurikulum, program praktikum dan ujian Histologi pada mahasiswa Fakultas Kedokteran Universitas Gadjah Mada Yogyakarta tahun 2003 - 2012.

\begin{tabular}{lccc} 
& \multicolumn{3}{c}{ Kelompok mahasiswa } \\
\cline { 2 - 4 } & $2003-2006$ & $2007-2010$ & $2011-2012$ \\
Kurikulum pendidikan dokter & 2002 & 2007 & 2007 \\
Rerata jumlah mahasiswa per tahun & 183,75 & 230 & 279 \\
Praktikum Histologi & & & \\
Sebaran Blok & $2-19$ & $2-7$ & $1-7$ \\
Jumlah blok dengan praktikum Histologi & 8 & 5 & 6 \\
Jumlah sesi praktikum & 19 & 17 & 19 \\
Jumlah preparat yang diamati & 65 & 50 & 59 \\
Jumlah soal ujian praktikum & 177 & 127 & 224 \\
Skor Praktikum & & & \\
Kuis awal praktikum & ya & Ya & Ya \\
Gambar yang dibuat mahasiswa & Ya & Tidak & Tidak \\
Kuis akhir praktikum & Tidak & Ya & Ya \\
Ujian Praktikum Histologi & & & Yidak \\
Peragaan dengan mikroskop & Ya & Ya & Ya \\
Foto ditayangkan dengan CD projector & Tidak & Tidak & Ya \\
Skor ujian praktikum menjadi komponen & Ya & Tidak & \\
akhir blok & & & \\
\hline
\end{tabular}

Pada tahun 2011-2012 praktikum dibagi dalam 6 blok, terbagi menjadi 19 sesi dan mengamati 59 preparat. Jumlah sesi praktikum dan jumlah preparat yang diamati tidak jauh berbeda pada ketiga kelompok. Ujian praktikum yang sebelumnya dilakukan dengan mengamati sediaan langsung di bawah mikroskop, pada tahun 2011 diganti dengan menggunakan tayangan foto di ruang kuliah dan skor praktikum digunakan kembali sebagai komponen nilai blok. Penggunaan tayangan foto memungkinkan penguji memberikan jumlah soal per sesi ujian lebih banyak. Bila dengan menggunakan mikroskop jumlah soal per sesi ujian berkisar antara 20-30 soal, maka dengan tayangan foto, soal yang diujikan menjadi 4050 soal per sesi ujian. Pada semua kelompok tersebut mahasiswa mengerjakan kuis awal praktikum sebelum mulai mengamati sediaan.
Mahasiswa S1 Program Studi Pendidikan Dokter Fakultas Kedokteran UGM pada tahun 2003 hingga 2012 berjumlah 2213 mahasiswa. Jumlah mahasiswa pada tahun 2003-2006 adalah 735 orang, pada tahun 2007-2010 sebanyak 920 orang dan tahun 2011-2012 sebanyak 558 orang. Ada peningkatan jumlah mahasiswa yang diterima pada tahun 2011. 2012. Jumlah mahasiswa yang meningkat tersebut membuat dosen harus memeriksa, menuliskan masukan dan memberi skor kuis jauh lebih banyak. Karena keterbatasan jumlah mikroskop, jumlah sesi ujian praktikum pun perlu lebih banyak untuk dapat menguji seluruh mahasiswa. Waktu yang dibutuhkan untuk menguji 30 mahasiswa berkisar 35-45 menit sehingga dibutuhkan waktu 4-5 jam untuk menyelenggarakan satu kali ujian praktikum. Ketika sistem ujian menggunakan foto yang ditayangkan di depan kelas, satu sesi ujian berlangsung selama 
35-45 menit juga, namun karena ujian dapat dilangsungkan pada kelas paralel maka satu sesi ujian dapat diikuti oleh 120 hingga 150 mahasiswa. Dengan demikian waktu yang dialokasikan untuk ujian hanya 90-120 menit saja. Metode ujian dengan tayangan foto ini memerlukan waktu yang lebih lama dalam persiapannya. Persiapan dilakukan dengan membuat foto sediaan dalam perbesaran lemah dan perbesaran kuat, menyusun pertanyaan dan memberikan tanda penunjuk pada foto yang ditayangkan. Namun demikian pekerjaan ini dapat dilakukan oleh satu orang instruktur setiap kali ujian sehingga secara keseluruhan tetap dapat menghemat waktu penyelenggaraan ujian. Ketika ujian dilakukan dengan peragaan sediaan pada mikroskop, lebih banyak instruktur yang harus bekerja menyiapkan soal ujian. Instruktur juga harus memeriksa kembali sediaan dan penunjuknya setiap kali sesi ujian berganti.
Rerata skor ujian praktikum Histologi masingmasing kelompok dapat dilihat pada tabel 2. Rerata skor tertinggi didapatkan pada kelompok tahun 2011-2012 yaitu 83,5 \pm 9 lebih tinggi dari rerata kedua kelompok lain (2003-2006:76,8 $\pm 7,4$; 2007 $2010: 74,5 \pm 14,4 ; \quad p<0,0001)$. Perbedaan program tahun 2011-2012 dengan tahun sebelumnya terletak pada ujian praktikum. Kelompok tahun 20112012 menggunakan tayangan foto di kelas sebagai bahan ujian, sedangkan kelompok lain mengamati peragaan sediaan dengan mikroskop saat ujian. Rerata skor praktikum kelompok tahun 2003-2006 dan 2007-2010 tidak berbeda bermakna walaupun ada perbedaan dalam program praktikum yaitu menggambar dibandingkan dengan kuis akhir praktikum serta skor digunakan pada penghitungan skor akhir blok dan tidak. Rentang waktu penyelenggaraan praktikum yang berbeda, blok 2-19 pada angkatan 2003-2006 dan blok 1-7 pada tahun 2007-2010 juga tidak menghasilkan perbedaan rerata skor ujian praktikum.

Tabel 2. Rerata skor praktikum dan distribusi mahasiswa dengan skor praktikum $<60$ dan skor praktikum $\geq 60$ pada tiap kelompok mahasiswa dengan program praktikum Histologi yang berbeda.

\begin{tabular}{lccc} 
& \multicolumn{3}{c}{ Kelompok Mahasiswa } \\
\cline { 2 - 4 } & $2003-2006$ & $2007-2010$ & $2011-2012$ \\
Jumlah mahasiswa (n) & 735 & 920 & 558 \\
Rerata skor ujian praktikum 90-100) & $76,8 \pm 7,4$ & $74,5 \pm 14,4$ & $83,5 \pm 9^{*}$ \\
Jumlah mahasiswa dengan skor ujian praktikum \# & & & \\
$<60$ & 711 & 761 & 14 \\
$\geq 60$ & 96,73 & 83,59 & 974 \\
$\%$ mahasiswa dengan skor praktikum $\geq 60$ & & & 97,49 \\
\hline
\end{tabular}

${ }^{*}$ T test value (two tailed; 0,05 ) $<0,0001$

\#chi square 125,2 , p value $<0,0001$

Dari data tersebut, terlihat bahwa penyelenggaraan ujian dengan tayangan foto menghasilkan skor ujian praktikum yang lebih tinggi mendukung laporan sebelumnya. ${ }^{2,3}$ Hal tersebut antara lain disebabkan karena pergeseran penunjuk yang terjadi ketika ujian dengan mikroskop dapat dihindari. Mahasiswa dapat melihat dengan jelas struktur yang ditanyakan saat ujian. Jumlah soal per sesi ujian yang lebih banyak, juga dapat memberi kontribusi pada skor yang lebih tinggi. Dengan jumlah soal yang sedikit maka satu jawaban salah akan memberi kontribusi besar pada skor keseluruhan. Foto perbesaran lemah dan kuat juga dapat ditayangkan berdampingan sehingga tayangan foto lebih banyak memberi informasi lokasi struktur yang ditanyakan pada soal. Mahasiswa di Universitas Palacky, Czech Republic dilaporkan 
lebih menyukai ujian dengan format elektronik dibandingkan dengan pengamatan langsung dengan mikroskop. ${ }^{3}$ Rasa suka tersebut dapat berakibat pada skor ujian yang lebih baik karena stres berkurang.

Di sisi lain, mahasiswa juga dapat membuat foto preparat sendiri dengan kamera digital saat praktikum dan bertukar foto dengan mahasiswa lain maupun mendapatkan foto dari kakak kelasnya. Dengan demikian, mahasiswa dapat melihat kembali foto preparat saat belajar tanpa perlu menggunakan mikroskop di ruang praktikum. Walaupun semua mahasiswa dapat datang ke laboratorium untuk menggunakan mikroskop di luar waktu praktikum di sepanjang jam kerja, tidak banyak mahasiswa yang memanfaatkan kesempatan tersebut. Dengan adanya foto digital preparat tersebut, mahasiswa memiliki akses yang tidak terbatas waktu untuk mempelajari materi praktikum. Hal tersebut mungkin dapat meningkatkan pemahaman mahasiswa seperti yang dilaporkan pada penggunaan mikroskop virtual saat praktikum di berbagai fakultas kedokteran. ${ }^{1-3}$

Penggunaan foto mikroskopik dalam praktikum histologi juga telah banyak dilaporkan menggeser penggunaan mikroskop cahaya di laboratorium. ${ }^{1}$ Dari sisi penyediaan bahan praktikum, penggunaan media digital juga dapat mengurangi waktu, tenaga dan biaya untuk penyediaan banyak sediaan histologis. Mahasiswa juga dilaporkan lebih menyukai belajar dengan media elektronik dibandingkan dengan penggunaan mikroskop. ${ }^{3,4}$ Walaupun penggunaan mikroskop virtual belum dijalankan secara resmi di laboratorium Histologi Fakultas Kedokteran UGM, namun besar kemungkinan mahasiswa juga memiliki ketertarikan yang sama besar pada penggunaan media visual digital. Beberapa fakultas kedokteran telah menggunakan media elektronik ini untuk meningkatkan aktivitas praktikum dari sekedar pengamatan menjadi kegiatan yang mendorong mahasiswa belajar secara integratif, aktif dan mandiri. ${ }^{5}$

Banyak staf pendidik berpendapat bahwa penggunaan foto digital untuk bahan praktikum sudah cukup untuk menggantikan pengamatan dengan mikroskop. ${ }^{4}$ Namun demikian banyak pengajar histologi dan juga para klinisi masih berpendapat bahwa mikroskop tetap harus menjadi bagian dari praktikum histologi di program studi pendidikan dokter. ${ }^{6}$ Keterampilan menggunakan mikroskop akan bermanfaat bagi mahasiswa ketika mereka belajar patologi, mikrobiologi dan parasitologi, praktik medis beberapa klinisi serta melakukan penelitian di bidang kedokteran.

Foto digital atau mikroskop virtual telah dilaporkan dapat digunakan sebagai media tambahan yang secara signifikan meningkatkan minat mahasiswa dalam belajar. ${ }^{7}$ Dalam penggunaan mikroskop virtual pun, skor praktikum histologi dilaporkan lebih baik ketika gambar yang dinamis digunakan sebagai media belajar dibandingkan foto statis. ${ }^{8}$ Tentunya adanya sediaan histologi yang bermutu perlu ada sebelum dapat membuat mikroskop virtual dan juga soal ujian menggunakan foto digital. 9 Selain penggunaan teknologi digital, adanya instruktur yang bersemangat mengajar juga dilaporkan merupakan faktor yang mempengaruhi hasil belajar mahasiswa., ${ }^{2,10}$ Di Fakultas Kedokteran UGM, pembelajaran dengan foto mikroskopik baru digunakan ketika menjelaskan struktur yang harus diamati dan sebagai soal kuis akhir praktikum. Kajian untuk mempertimbangkan peningkatan penggunaan foto digital untuk membuat program praktikum yang lebih interaktif dan berpusat pada mahasiswa perlu dilakukan, mengingat kecenderungan yang ada di dunia saat ini. ${ }^{1,4,11}$

Pada tabel 2 dapat dilihat distribusi mahasiswa dengan skor ujian praktikum $<60$ dan yang $\geq 60$. Persentase mahasiswa dengan skor $\geq 60$ tertinggi didapatkan pada kelompok 2011-2012 (97,49\%). Persentase tersebut tidak berbeda bermakna dari mahasiswa tahun 2003-2006 (96,73\%). Persentase mahasiswa angkatan 2007-2010 yang memiliki skor ujian praktikum Histologi $\geq 60$ ada di peringkat terbawah yaitu $83,59 \%$. Perbedaan jumlah mahasiswa dengan skor $\geq 60$ pada kelompok ini dengan kelompok lain secara statistik bermakna ( $\mathrm{p}<0.0001)$. Skor praktikum yang digunakan dalam penghitungan skor akhir blok (2003-2006 \& 2011-2012) kemungkinan dapat memicu mahasiswa yang ada di peringkat bawah untuk belajar lebih banyak sehingga persentase mahasiswa yang skor ujian praktikumnya $\geq 60$ lebih banyak dibandingkan dengan kelompok yang tidak 
menggunakan skor praktikum dalam penghitungan skor blok. Walaupun demikian, rerata skor ujian praktikum pada kedua kelompok tersebut tidak berbeda bermakna. Pada tahun 2007-2010, mahasiswa yang skornya $<60$ dapat mengulang ujian praktikum untuk bisa mendapatkan surat puas. Kesempatan mengulang tersebut kemungkinan membuat beberapa mahasiswa menunda belajar Histologi dan belajar materi yang lain. Dari sisi instruktur, banyaknya mahasiswa yang harus mengulang memberi tambahan beban pekerjaan tersendiri. Ketika skor praktikum digunakan sebagai komponen skor akhir blok, mahasiswa lebih memiliki motivasi untuk belajar lebih baik karena tidak ada kesempatan mengulang dan skor yang didapat menjadi bagian dari skor yang menentukan nilai akhir. Hingga saat ini, skor praktikum digunakan dalam penghitungan skor blok dan terbukti memberikan hasil yang lebih baik.

Pada program pendidikan dokter, Histologi diharapkan dipelajari secara terintegrasi untuk memahami anatomi dan fisiologi tubuh manusia normal serta merupakan dasar untuk mempelajari ilmu-ilmu paraklinik dan klinik. Praktikum merupakan suatu program pembelajaran yang melibatkan aspek psikomotorik mahasiswa. Apakah metode praktikum dan ujian yang ada sekarang sudah tepat untuk menghasilkan pemahaman histologi yang kuat yang akan meningkatkan dasar mempelajari ilmu-ilmu patologi dan klinik tentunya perlu dievaluasi dan dikembangkan pula.

\section{KESIMPULAN}

Dari data yang dianalisis dapat disimpulkan bahwa rerata skor ujian praktikum Histologi lebih tinggi pada mahasiswa yang diuji dengan tayangan foto dibandingkan mahasiswa yang diuji dengan peragaan sediaan pada mikroskop. Penggunaan skor praktikum sebagai komponen skor akhir blok menghasilkan persentase mahasiswa dengan skor ujian praktikum Histologi $\geq 60$ yang lebih banyak.

\section{KONTRIBUSI PENULIS}

RS mengusulkan ide penelitian, merangkum data dan menulis rancangan awal naskah, JF melakukan analisis data skor praktikum dan uji statistik, YA melakukan revisi naskah.

\section{UCAPAN TERIMAKASIH}

Penulis berterimakasih kepada Teguh Sugiharto yang telah membantu mengumpulkan data dari arsip untuk dianalisis.

\section{DAFTAR PUSTAKA}

1. Paulsen FP, Eichhorn M, Bräuer L. Virtual microscopy - the future of teaching histology in the medical curriculum? Ann. Anat. 2010;192:378-82.

2. Heidger PM, Dee F, Consoer D, Leaven T, Duncan $\mathrm{J}$, Kreiter C. Integrated approach to teaching and testing in histology with real and virtual imaging. Anat. Rec. 2002;269:107-12.

3. Lichnovska R, Krajci D, Erdosova B, Krajci D. Our experience with e-learning method of teaching practical histology. MEFANET J 2015;3(2):48-53.

4. Glaltz-Krieger K, Spornitz U, Spatz A, Mihatsch MJ, Glatz D. Factors to keep in mind when introducing virtual microscopy. Virchows Arch. 2006;448:24855 .

5. Munoz AL, Lopez JL. Use of virtual microscopy to promote Histology learning. A Mendez-Vilas A (ed). Microscopy: advances in Scientific research and education; 2014, pp. 1210-3.

6. Pratt RL. Are we throwing histology out with the microscope? A look at histology from the physician's perspective. Anat. Sci. Educ. 2009;2:205-9.

7. Bloodgood RA, Ogilvie RW. Trends in histology laboratory teaching in United states Medical Schools. Anat. Rec 2006;289B:169-75.

8. Mione S, Valcke M, Cornelissen R. Evaluation of virtual microscopy in medical histology teaching. Anat. Sci. Educ. 2013;6(5):307-15.

9. Coleman R. Can histology and pathology be taught without microscopes? The advantages and disadvantages of virtual histology. Acta Histochem 2009; 111:1-4

10. Scoville SA, Buskirk TD. Traditional and virtual microscopy compared experimentally in a classroom setting. Clin Anat. 2007;20:565-70.

11. Drake RL, McBride JM, Lachman N, Pawlina W. Medical education in anatomical Science: The winds of change continue to blow. Anat. Sci. Educ. 2009;2:253-9. 